\title{
PENGARUH PERPUTARAN KAS, PERPUTARAN PIUTANG, DAN PERPUTARAN PERSEDIAAN TERHADAP PROFITABILITAS PADA PERUSAHAAN OTOMOTIF DAN KOMPONEN YANG TERDAFTAR DI BURSA EFEK INDONESIA TAHUN 2010-2014.
}

\author{
Nansy Herina \\ NansyHerina1909@gmail.com
}

\begin{abstract}
ABSTRAK
Tujuan dilakukan Penelitian ini adalah untuk menganalisis pengaruh Perputaran Kas, Perputaran Piutang, dan Perputaran persediaan terhadap Profitabilitas (Studi Pada Perusahaan Sektor Otomotif dan Komponen yang terdaftar di Bursa Efek Indonesia ).

Metode penelitian yang digunakan dalam penelitian ini adalah metode deskriptif verifikatif, karena adanya variabel-variabel yang akan ditelaah hubungannya serta tujuannya untuk menyajikan gambaran secara terstruktur, factual, dan akurat mengenai fakta-fakta serta hubungan antar variabel yang diteliti, yaitu Pengaruh Perputaran Kas, Perputaran Piutang dan Perputaran Persediaan terhadap Profitabilitas.

Penelitian ini dilakukan pada perusahaan sektor otomotif dan komponen yang terdaftar di Bursa Efek Indonesia dengan jumlah sampel 7 perusahaan.

Dari hasil analisis data penelitian, diperoleh simpulan sebagai berikut :

1. Nilai rata-rata perputaran kas paling tinggi adalah PT. Nipres Tbk, nilai ratarata perputaran piutang paling tinggi PT. Multistrada Arah Sarana, Tbk, dan Nilai rata-rata perputaran persediaan paling tinggi adalah PT. Astra Internasional Tbk.

2. Nilai rata-rata profitabilitas paling tinggi adalah PT. Astra Internasional Tbk.

3. Secara simultan Perputaran Kas, Perputaran Piutang dan Perputaran Persediaan terdapat pengaruh positif dan signifikan terhadap Profitabilitas.

4. Secara Parsial Perputaran Kas, Perputaran Piutang dan Perputaran Persediaan berpengaruh positif dan tidak signifikan terhadap Profitabilitas.
\end{abstract}

Kata Kunci : Profitabilitas, Perputaran Kas, Perputaran Piutang, Perputaran Persediaan

\section{ABSTRACT}

Nansy Herina. 1441173405043.2016. The Influence of Cash Turnover, Account Receivable Turn Over and Inventory Turn Over towards Profitability on Automotive and Component Companies Registered in Indonesia Stock Exchange 2010-2014 Period. 
The Purpose of research is to analyze effect the Cash Turn Over, Account Receivable Turn Over and Inventory Turn Over to Profitability (Study in the Automotive and Components Sector that Listed on Indonesia Stock Exchange).

The used method of the research is descriptive verifikatif, since there are variables that will be analyzed for the correlation. The purpose of the analyze is to provide and organized, factual, and accurate about facts correlations between the analyzed variable which are, Effecct the Cash Turn Over, Account Receivable Turn Over and Inventory Turn Over to Profitability.

The research is conducted at companies in the automotive and component sector entrolled in Indonesia stock exchange with the total sample as 7 companies.

From the research data analysis is obtained conclusions as follows:

1. The highest score of the average cash turn over is PT. Nipres, Tbk, the highest score of the average account receivable turn over is PT. Multistrada Arah Sarana, Tbk, the highest score of the average inventory turn over is PT. Astra Internasional, Tbk.

2. The highest score of the average profitability is PT. Astra Internasional, Tbk.

3. Simultaneously cash turn over, Account receivable turn over and inventory turn over have positive and significant influence towards profitability.

4. Partially, cash turn over, account receivable turn over and inventory turn over have positive and significant influence toward profitability.

Key Words : Profitability, Cash Turn Over, Account Receivable Turn Over, Inventory Turn Over

\section{PENDAHULUAN}

Perkembangan industri otomotif di tanah air patut dibanggakan karena membawa dampak yang sangat luas, tidak hanya industri komponen bertumbuh tetapi juga dapat membuka lapangan kerja dan jasa terkait. Hal ini terlihat dari jumlah investasi di sektor otomotif yang terus meningkat secara signifikan. Industri komponen lokal juga semakin meningkatkan kapasitas produksinya untuk memasok kebutuhan dalam negeri sehingga mendorong terjadinya peningkatan kandungan lokal dan secara bertahap komponen impor semakin mengecil yang pada gilirannya dapat tergantikan oleh komponen lokal. Kemampuan industri dalam negeri dalam mengembangkan industri otomotif merupakan bukti semakin tingginya kemampuan dan penguasaan teknologi yang dimiliki oleh tenaga kerja Indonesia secara terus menerus berupaya meningkatkan kompetensinya.

Struktur industri komponen saat ini masih kurang kuat dan lengkap, terutama untuk komponen dengan presisi dan teknologi tinggi, seperti engine dan power train. Selain itu, industri otomotif Indonesia ternyata masih kalah bersaing dengan negara-negara tetangga, seperti Thailand, dari berbagai sisi. Ambil contoh dari sisi produksi kendaraan roda empat, Indonesia berada di posisi kedua di bawah Negeri Gajah Putih.Untuk mendorong pengembangan komponen otomotif di dalam negeri, Kementerian Perindustrian sudah menjalankan program low cost and green car yang mengharuskan penggunaan komponen lokal. Selain itu, pemerintah juga sedang memformulasikan program percepatan penguasaan teknologi dan 
pengembangan produk yang belum dapat diproduksi di dalam negeri. Apalagi, sebagian besar industri komponen nasional berada di skala kecil dan menengah.

Direktur Jenderal Industri Kecil dan Menengah (IKM) Kementerian Perindustrian Euis Saedah mengatakan, pertumbuhan industri komponen otomotif skala kecil dan menengah memang masih kecil. Pasalnya, sampai saat ini belum ada lembaga yang menampung aspirasi koperasi industri komponen otomotif. Selain itu, pada umumnya industri ini tersebar luas di berbagai daerah.

Pemerintah sudah berusaha untuk memfasilitasi dengan menempatkan IKM komponen otomotif tersebut di kawasan industri seperti di Jababeka agar bisa dekat dengan industri otomotif. Namun, menurut Euis, menempatkan IKM di dalam kawasan industri tidak mudah karena terbentur oleh sewa lahan yang mahal. Pada akhirnya, keinginan untuk mewujudkan klaster industri komponen di kawasan industri harus pudar. Menurut Euis, penguatan kapasitas kelembagaan nggak mudah dan salah satu kerepotan yang dialami adalah izin usaha industri di daerah dan mendapatkan lokasi khusus untuk sentra IKM. Selanjutnya, Euis menjelaskan, pemberian fasilitas kepada IKM komponen otomotif tidak hanya berhenti sampai di situ. Kemenperin telah memberikan pelatihan dan pendampingan untuk mendapatkan kompetensi sumber daya manusia (SDM). Selain itu, ada pula bantuan restrukturisasi mesin dalam bentuk subsidi. Di industri otomotif, bantuan ini baru berjalan selama dua tahun. Skema bantuan tersebut, yakni pemerintah memberikan subsidi 45 persen bagi mesin-mesin yang berasal dari dalam negeri dan subsidi 35 persen diberikan untuk mesin impor.

Direktur INDEF (Institute for Development of Economic and Finance) Enny Sri Hartati mengatakan, semestinya kebijakan untuk mengembangkan industri otomotif dilakukan melalui dua jalur, yakni jalur industri dan jalur perdagangan. Jalur industri diawali dengan penyiapan bahan baku yang digunakan dan SDM. Material bahan baku bisa berupa material mentah, seperti besi dan material setengah jadi seperti komponen. Sedangkan, jalur perdagangan, yakni dengan mengimpor kendaraan jadi atau CBU. Saat ini regulasi pemerintah terkesan justru berpihak atau memudahkan untuk jalur perdagangan dengan memberikan free biaya masuk melalui skema FTA. Kebijakan jalur industri justru dipersulit dengan pemberian biaya masuk impor untuk komponen sebagai material industri. Padahal, jalur industri menyerap lapangan kerja sekaligus menjadi sumber penerimaan pajak bagi negara. Oleh karena itu, tak heran jika banyak industri kendaraan bermotor yang memberhentikan produksinya dan memilih untuk mengimpor mobil untuk memenuhi pasar di Indonesia. Beberapa regulasi yang sudah dibuat oleh pemerintah sebenarnya sudah jelas, yakni untuk mendukung industri otomotif dan memperbesar produksinya. Namun, sangat disayangkan kebijakan ini belum dilakukan secara konsisten dan belum ada harmonisasi. Dengan kondisi saat ini, hal yang diutamakan adalah menyelesaikan persoalan produksi dari berbagai aspek, termasuk pembiayaan, transfer teknologi, dan pengembangan IKM komponen otomotif. (Sumber : Republika, 2015)

Perusahaan sub sektor otomotif dan komponen merupakan bagian dari sektor aneka industri Perusahaan Manufaktur. Sektor perindustrian merupakan salah satu sektor yang menjadi acuan perkembangan suatu negara, salah satunya industri otomotif yang berkembang pesat di Indonesia. Berkembang pesatnya industri otomotif di Indonesia dikarenakan meningkatnya kebutuhan manusia akan alat transportasi pribadi maupun umum. Produk yang dihasilkan oleh industri 
otomotif dan komponen adalah suku cadang kendaraan bermotor, komponen mesin, komponen badan kendaraan bermotor, dan aksesoris kendaraan. Industri otomotif dan komponen yang terdaftar di Bursa Efek Indonesia tahun 2014 adalah sebanyak 12 perusahaan, berdasarkan saham ok (www.sahamok.com). Perputaran kas pada perusahaan otomotif dan komponen yang terdaftar di Bursa Efek Indonesia Tahun 2010 sampai dengan 2014 sangat bervariasi. Kondisi perputaran Kas terburuk pada perusahaan otomotif dan komponen yang terdaftar di Bursa Efek Indonesia apabila dilihat dari rata-rata adalah Tahun 2013, karena semakin rendah tingkat perputaran Kas maka semakin sulit kas yang dimiliki untuk dicairkan dalam waktu singkat sehingga perusahaan harus bekerja dengan kas yang lebih sedikit. Kondisi perputaran piutang terbaik pada perusahaan otomotif dan komponen yang terdaftar di Bursa Efek Indonesia Tahun 2010 sampai dengan 2014 adalah Tahun 2012, karena semakin tinggi perputaran piutang menujukkan modal kerja yang di dalam piutang rendah, sebaliknya kondisi Tahun 2013 adalah kondisi terburuk karena semakin rendah perputaran piutang artinya ada over investmesnt dalam piutang sehingga, memerlukan analisa lebih lanjut, mungkin karena bagian kredit dan penagihan bekerja tidak efektif atau mungkin ada perubahan dalam kebijakan pemberian kredit. Kondisi perputaran persediaan yang terbaik pada perusahaan otomotif dan komponen yang terdaftar di Bursa Efek Indonesia Tahun 2010 sampai dengan 2014 adalah pada Tahun 2010, karena semakin tinggi tingkat perputaran persediaan menunjukkan perusahaan bekerja secara efisien dan likuid persediaan semakin baik. Sedangkan kondisi terburuk adalah Tahun 2014, karena pada Tahun ini menunjukkan tingkat perputaran persediaan paling rendah dibandingkan tahun sebelumnya, yang berarti pada Tahun 2014 perusahaan bekerja tidak efisien atau tidak produktif dan banyak barang persediaan yang menumpuk.

Berdasarkan uraian di atas penulis tetarik untuk meneliti lebih dalam tentang perputaran kas, perputaran piutang, perputaran persediaan, dan profitabilitas pada perusahaan publik yang bergerak dalam bidang otomotif dan komponen dengan mengajukan judul penelitian tesis: PENGARUH PERPUTARAN KAS, PERPUTARAN PIUTANG DAN PERPUTARAN PERSEDIAAN TERHADAP PROFITABILITAS PADA PERUSAHAAN OTOMOTIF DAN KOMPONEN YANG TERDAPAT DI BEI TAHUN 2010 2014.

\section{IDENTIFIKASI MASALAH}

Berdasarkan pada data, pendapat, dan hasil penelitian di latar belakang penelitian maka identifikasi masalah penelitian tesis ini adalah sebagai berikut:

1. Profitabilitas perusahaan otomotif dan komponen yang terdaftar di BEI tahun 2010-2014 ada yang dibawah 0\%

2. Perusahaan yang memiliki tingkat profitabilitas paling tinggi diantara perusahaan lain bukan merupakan perusahaan yang memiliki tingkat perputaran kas, perputaran piutang dan persediaan paling tinggi.

3. Sebagian Perusahaan otomotif dan komponen yang terdapat di BEI tahun 20102014 masih belum efisiensi dalam menujukkan tingkat perputaran kasnya.

4. Perputaran kas pada perusahaan otomotif dan komponen yang terdaftar di BEI memiliki pengaruh parsial terhadap profitabilitas. 
5. Hanya ada 1 perusahaan dari 12 perusahaan otomotif dan komponen yang terdaftar di BEI tahun 2010-2014 yang berada di atas rata-rata tingkat perputaran piutangnya.

6. Perputaran piutang pada perusahaan otomotif dan komponen yang terdaftar di BEI memiliki pengaruh parsial terhadap profitabilitas.

7. Sebagian Perusahaan otomotif dan komponen yang terdapat di BEI tahun 20102014 masih belum efisiensi dan efektif dalam menujukkan tingkat perputaran persediaannya.

8. Perputaran persediaan pada perusahaan otomotif dan komponen yang terdaftar di BEI memiliki pengaruh parsial terhadap profitabilitas.

\section{PEMBATASAN MASALAH}

Berdasarkan latar belakang masalah dan identifikasi masalah, maka penelitian ini membatasi permasalahan pada :

1. Penelitian ini hanya berkaitan dengan bidang ilmu manajemen keuangan

2. Objek penelitian dalam tesis ini adalah perputaran kas, perputaran piutang, perputaran persediaan dan profitabilitas (ROA dan ROE).

3. Unit analisis dalam tesis ini adalah Perusahaan Otomotif dan Komponen yang terdapat di BEI Tahun 2010-2014.

4. Metode analisis yang digunakan yaitu metode analisis deskriptif dan verifikatif.

5. Metode alat bantu yang digunakan yaitu metode regresi linear berganda.

\section{RUMUSAN MASALAH}

Adapun permasalahan yang akan dikemukakan penulis sebagai berikut:

1. Bagaimana Perputaran Kas, Perputaran Piutang, Perputaran Persediaan pada perusahaan otomotif dan komponen yang terdapat di BEI tahun 2010-2014.

2. Bagaimana Profitabilitas pada perusahaan otomotif dan komponen yang terdapat di BEI tahun 2010-2014.

3. Seberapa besar pengaruh Perputaran Kas, Perputaran Piutang, Perputaran Persediaan secara simultan terhadap Profitabilitas pada perusahaan otomotif dan komponen yang terdapat di BEI tahun 2010-2014.

4. Seberapa besar pengaruh Perputaran Kas, Perputaran Piutang, Perputaran Persediaan secara parsial terhadap Profitabilitas pada perusahaan otomotif dan komponen yang terdapat di BEI tahun 2010-2014

\section{TINJAUAN PUSTAKA}

\section{MANAJEMEN}

Wilson Bangun (2005:299) mengemukakan Manajemen ialah rangkaian aktivitas-aktivitas yang dikerjakan oleh anggota-anggota organisasi untuk mencapai tujuannya. Proses merupakan rangkaian kegiatan yang dilakukan secara sistematis. Merujuk pada manajemen sebagai suatu proses, para manajer dalam melaksanakan aktivitasnya saling terkait dengan sasaran yang mereka capai.

Griffin (2004:8) menyebutkan bahwa manajemen sebagai suatu rangkaian aktivitas (termasuk perencanaan dan pengambilan keputusan, pengorganisasian, kepemimpinan, dan pengendalian) yang diarahkan pada sumber daya-sumber daya organisasi (manusia, finansial, fisik, dan informasi) untuk mencapai tujuan 
organisasi dengan cara yang efektif dan efisien. Efektif berarti membuat keputusan yang tepat dan mengimplementasikannya dengan sukses. Efisien berarti menggunakan sumber daya - sumber daya secara bijaksana dan dengan cara menghemat biaya. Orang yang bertanggungjawab dalam melaksanakan proses manajemen adalah seorang manajer.

Menurut Stoner yang dikutip oleh Wijayanti (2008:1) manajemen adalah "proses perencanaan, pengorganisasian, pengarahan, dan pengawasan usaha-usaha para anggota organisasi dan penggunaan sumber daya - sumber daya manusia organisasi lainnya agar mencapai tujuan organisasi yang telah ditetapkan".Menurut Kotler dan Keller (2012: 131), mendefinisikan kualitas pelayanan adalah kemampuan perusahaan untuk memuaskan kebutuhan dan keinginan konsumen. Berdasarkan definisi ini, kualitas pelayanan ditentukan oleh kemampuan perusahaan memenuhi kebutuhan dan keinginan konsumen sesuai dengan ekspektasi konsumen.

Adapun fungsi-fungsi manajemen menurut George R. Terry (dalam Handoko, 2003:22-25) adalah:

1. Perencanaan (planning) adalah pemilihan atau penetapan tujuan-tujuan organisasi dan penentuan strategi, kebijaksanaan, proyek, program, prosedur, metoda, sistem, anggaran, dan standar yang dibutuhkan untuk mencapai tujuan. Pembuatan keputusan banyak terlibat dalam fungsi ini.

2. Pengorganisasian (organizing) yaitu (1) penentuan sumber daya-sumber daya dan kegiatan-kegiatan yang dibutuhkan untuk mencapai tujuan organisasi, (2) perancangan dan pengembangan suatu organisasi atau kelompok kerja yang akan dapat "membawa" hal-hal tersebut ke arah tujuan, (3) penugasan tanggung jawab tertentu, (4) pendelegasian wewenang yang diperlukan kepada individuindividu untuk melaksanakan tugas-tugasnya.

3. Penggerakan / pengarahan (actuating), yaitu untuk menggerakan organisasi agar berjalan sesuai dengan pembagian kerja masing-masing serta menggerakan seluruh sumber daya yang ada dalam organisasi agar pekerjaan atau kegiatan yang dilakukan bisa berjalan sesuai rencana dan bisa mencapai tujuan. Fungsi actuating sering disebut dengan bermacam-macam nama, antara lain leading, directing, motivating.

4. Pengawasan / pengendalian (controlling) Semua fungsi terdahulu tidak akan efektif tanpa fungsi controlling. Pengawasan (controlling) adalah penemuan dan penerapan cara dan peralatan untuk menjamin bahwa rencana telah dilaksanakan sesuai dengan yang telah ditetapkan.

\section{MANAJEMEN KEUANGAN}

Menurut Agus Sartono (2009), Manajemen keuangan dapat diartikan sebagai manajemen dana, baik yang berkaitan dengan pengalokasian dana dalam berbagai bentuk investasi secara efektif maupun usaha pengumpulan dana untuk pembiayaan investasi atau pembelanjaan secara efisien.

Agus Harjito (2010:59) mengemukakan manajemen keuangan adalah segala aktivitas perusahaan yang berhubungan dengan bagaimana memperoleh dana, bagaimana menggunakan dana dan bagaimana mengelola aset sesuai tujuan perusahaan secara menyeluruh. Dengan kata lain manajemen keuangan merupakan manajemen mengenai bagaimana memperoleh aset, mendanai aset, dan mengelola aset sesuai tujuan perusahaan. 
Bambang Riyanto (2011) menjelaskan bahwa manajemen keuangan adalah keseluruhan aktivitas yang terkait dengan usaha untuk mendapatkan dana dan menggunakan atau mengalokasikan dana tersebut.

James C. Van Horne dan John M. Wachowichz (2005:3) mendefinisikan manajemen keuangan sebagai "manajemen yang berkaitan dengan perolehan, pendanaan dan manajemen aktiva dengan beberapa tujuan umum sebaga latar belakang". Menurut Sutrisno (2009:3) manajemen keuangan adalah "semua aktivitas perusahaan yang berhubungan dengan usaha-usaha mendapatkan dana perusahaan dengan biaya yang murah serta usaha untuk menggunakan dan mengalokasikan dana tersebut secara efisiensi.

\section{MODAL KERJA}

Modal kerja menurut Agnes Sawir (2003:129) adalah keseluruhan aktiva lancar yang dimiliki oleh perusahaan, atau dapat pula dimaksudkan sebagai dana yang harus tersedia untuk membiayai kegiatan operasi perusahaan sehari-hari. J. Fred Weston dan Eugene F. Brigahm (Kutipan Agnes Sawir, 2003:129) menyatakan bahwa Modal kerja adalah investasi perusahaan didalam aktiva jangka pendek seperti kas, sekuritas (surat-surat berharga), piutang dagang dan persediaan.

Menurut Burton A. Kolb (kutipan Agnes Sawir, 2003:129) mengemukakan bahwa: "Working capital is the investment of the firm in short-term or current assets, which includes cash, marketable securities, account receivable, short-term notes receivales, inventories, and in some firms, expense prepayments. (Modal kerja adalah investasi perusahaan dalam aktiva jangka pendek atau lancar, termasuk didalamnya kas, sekuritas, piutang, persediaan, dan dalam beberapa perusahaan, biaya dibayar dimuka)".

Menurut Lukas Setia Atmaja (2003:365) mengemukakan bahwa: "Modal kerja atau working capital, sering pula disebut grossworking capitalatau modal kerja kotor. Didefinisikan sebagai item-item pada aktiva lancar, yakni: (cash), sedangkan modal kerja bersih atau net working capital adalah aktiva lancar setelah dikurangi dengan hutang lancar".

Modal kerja sendiri mempunyai jenis-jenis tertentu yang disebutkan sesuai dengan kapasitas tau kondisi kebutuhan modal kerja dalam suatu perusahaan. Menurut Sri Dwi Ari Ambarwati dan Bambang Riyanto (2010:112) yang berdasarkan pendapat AW Taylor, modal kerja dibedakan menjadi dua, yaitu : Modal kerja permanen adalah modal kerja minimal yang harus ada dalam perusahaan untuk memenuhi kebutuhan konsumen berupa barang jadi. Modal kerja permanen dibedakan menjadi :

Modal kerja primer adalah modal kerja minimal yang harus dimiliki perusahaan agar dapat terus beroperasi.

Modal kerja normal adalah modal kerja yang harus ada dalam perusahaan agar dapat beroperasi dalam kapasitas normal

Modal kerja variabel adalah modal kerja yang selalu berubah proporsional dengan perubahan kapasitas produksi. Modal kerja ini terdiri dari :

Modal kerja musiman adalah modal kerja yang berubah sesuai perubahan musim/permintaan, misalnya permintaan yang besar pada waktu hari raya.

Modal kerja skils adalah modal kerja yang berubah akibat fluktuasi konjungtor. 
Modal Kerja darurat adalah modal kerja yang berubah sesuai denga keadaan yang terjadi di luar kemampuan perusahaan.Menurut Phillip Kotler dan Kevin Lane Keller (2007:177), kepuasan konsumen adalah perasaan senang atau kecewa seseorang yang muncul setelah membandingkan kinerja (hasil) produk yang dipikirkan terhadap kinerja yang diharapkan.

\section{RASIO KEUANGAN}

Menurut Kasmir (2014:104) rasio keuangan adalah "kegiatan membandingkan angka-angka yang ada dalam laporan keuangan dengan cara membagi satu angka dengan angka lainnya." Munawir (2000:54) rasio menggambarkan suatu hubungan atau perimbangan (mathematical relationship) antara suatu jumlah tertentu dengan jumlah yang lain. Rasio sebenernya adalah alat yang dinyatakan dalam arithmetical terms yang dapat digunakan untuk menjelaskan hubungan antara dua macam data finansial (Riyanto, 2008:329).

Pengertian rasio keuangan menurut James C. Van Horne dalam Kasmir (2010:104) adalah sebagai berikut : "Rasio keuangan merupakan indeks yang menghubungkan dua angka akuntansi dan diperoleh dengan membagi satu angka dengan angka lainnya. Rasio keuangan digunakan untuk mengevaluasi kondisi keuangan dan kinerja perusahaan. Dari hasil rasio keuangan ini akan terlihat kondisi kesehatan perusahaan yang bersangkutan."

Pengertian rasio keuangan menurut Sofyan Syafri Harahap (2009:297) adalah sebagai berikut : "Rasio keuangan adalah angka yang diperoleh dari hasil perbandingan dari satu pos laporan keuangan dengan pos lainnya yang mempunyai hubungan yang relevan dan signifikan (berarti)."

\section{Paradigma Penelitian}

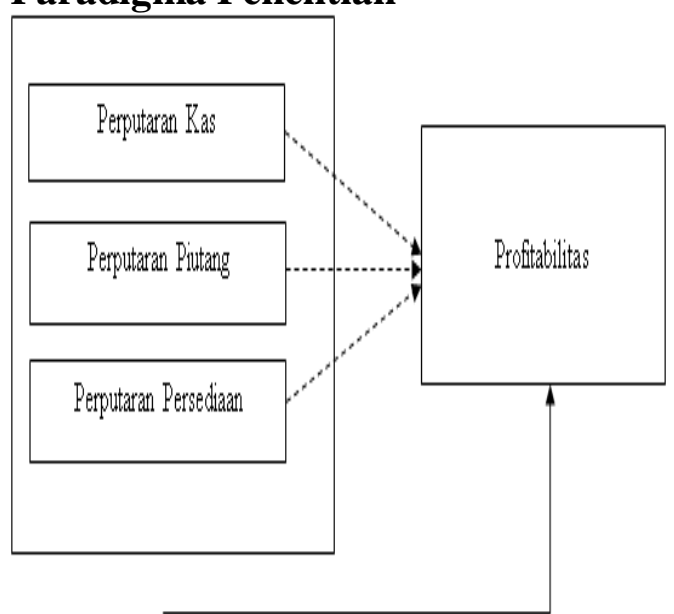

Gambar 1. Paradigma Penelitian

\section{Hipotesa Penelitian}

Dalam penelitian ini hipotesis yang diajukan adalah :

1. Terdapat pengaruh perputaran kas, perputaran piutang dan perputaran persediaan secara simultan terhadap profitabilitas pada perusahaan otomotif dan komponen yang terdapat di BEI tahun 2010 - 2014. 
2. Terdapat pengaruh perputaran kas, perputaran pitang dan perputaran persediaan secara parsial terhadap profitabilitas pada perusahaan otomotif dan komponen yang terdapat di BEI tahun 2010 - 2014.

\section{METODE PENELITIAN \\ METODE YANG DIGUNAKAN}

Metode yang akan digunakan dalam penelitian ini adalah metode deskriptif dan verifikatif, karena adanya variabel-variabel yang akan ditelaah keterkaitannya. Metode deskriptif adalah suatu metode dalam meneliti status kelompok manusia, suatu obyek, suatu kondisi, suatu sistem pemikiran ataupun suatu kelas peristiwa pada masa sekarang. Menurut Husein Umar (2009 : 22) metode ini bertujuan untuk menggambarkan sifat sesuatu yang tengah berlangsung pada saat penelitian dilakukan dan memeriksa sebab-sebab dari suatu gejala tertentu. Metode verifikatif digunakan untuk mengetahui hubungan antara variabel melalui pengujian hipotesis.

Menurut Arikunto (2009:234) penelitian deskriptif tidak dimaksud untuk menguji hipotesis tertentu, tetapi hanya menggambarkan apa adanya tentang suatu variabel, gejala atau keadaan. Metode ini dipergunakan untuk meneliti masalahmasalah yang sedang berlangsung pada masa sekarang dengan menjelaskan dan memahami apa yang ada, pendapat yang berkembang, proses berlangsung dan akibat dan efek yang tengah terjadi. Penelitian ini akan menyajikan gambaran secara terstrukur, faKtual, dan akurat mengenai fakta-fakta serta hubungan antar variabel yang diteliti, yaitu pengaruh Perputaran Kas, Perputaran Piutang, dan Perputaran Persediaan terhadap Profitabilitas.

Sedangkan analisis verifikatif adalah analisis model dan pembuktian yang berguna untuk mencari kebenaran dari hipotesis yang diajukan. Analisis verifikatif merupakan analisis untuk membuktikan dan mencari kebenaran dari hipotesis yang dilakukan. Analisis ini bermaksud untuk mengetahui hasil penelitan berkaitan dengan pengaruh Perputaran Kas, Perputaran Piutang, perputaran Persediaan terhadap Profitabilitas.

\section{Operasionalisasi Variabel}

Dalam penelitian ini variabel yang diteliti dibagi menjadi dua kelompok besar, yaitu variabel bebas (independent variable) dan variabel terikat (dependen variable). Variabel bebas adalah variabel yang nilainya tidak tergantung dari variabel yang lain dan variabel terikat adalah variabel yang nilainya tergantung dari variabel lain. Dalam penelitian ini Variabel bebasnya adalah Perputaran Kas (X1), Perputaran Piutang (X2) dan Perputaran Persediaan (X3), sedangkan variabel terikatnya adalah Profitabilitas (Y), yang dalam penelitian ini hanya dilihat dari segi Return On Asset.

\section{Sumber Dan Cara Penentuan Data/Informasi}

Data yang dipergunakan dalam penelitian ini, adalah data sekunder yaitu data yang bukan diusahakan sendiri pengumpulannya oleh peneliti (Riduwan, 2010:97). Data sekunder diperoleh dari berbagai bahan pustaka, baik berupa buku, jurnaljurnal, laporan keuangan perusahaan dari Bursa Efek Indonesia dan dokumen lainnya yang ada hubungannya dengan materi kajian. Dalam penelitian ini, data yang diperoleh adalah dari hasil analisis secara langsung terhadap dokumen dan 
data-data yang ada pada Bursa Efek Indonesia yaitu, laporan keuangan perusahaan otomotif dan komponen tahun 2010 sampai dengan 2014. Data yang digunakan dalam penelitian ini dikumpulkan dengan menggunakan metode historis dan secara online, berupa laporan keuangan yang berasal dari website resmi yang dimiliki oleh Bursa Efek Indonesia, yaitu www.idx.co.id.

\section{Populasi Dan Sampel}

Populasi penelitian ini adalah perusahaan otomotif dan komponen yang yang terdapat di Bursa Efek indonesia dari tahun 2010 sampai dengan 2014 yang berjumlah 12 perusahaan. Sedangkan sampel yang diambil dengan teknik purposive sampling untuk memperoleh data dalam penelitian ini yaitu 7 sampel yang termasuk kategori perusahaan otomotif dan komponen yang menerbitkan laporan keuangan di Bursa Efek Indonesia (BEI) secara berturut-turut per triwulan dalam periode Tahun 2010 sampai dengan Tahun 2014 adalah sebanyak 140 data.Dalam penelitian ini populasinya adalah pengunjung di Rumah Makan Waroeng Desa Karawang.

\section{Teknik Pengumpulan Data}

Pengumpulan data dilakukan dengan menggunakan metode dokumentasi yaitu dengan mencari data mengenai hal atau variabel yang berupa data-data tertulis seperti buku-buku, majalah, dokumen, peraturan-peraturan, catatan harian. Data dalam penelitian ini merupakan data sekunder dan sampel yang digunakan yang didarkan pada laporan keuangan yang dipublikasikan melalui website Bursa Efek Indonesia yang resmi, yaitu www.idx.co.id. Data yang dipergunakan adalah laporan keuangan perusahaan otomotif dan komponen Triwulan I sampai dengan Triwulan IV Tahun 2010 sampai dengan Tahun 2014.

\section{Rancangan Analisis dan Uji Hipotesis}

\section{Rancangan Analisis Regresi Berganda}

Analisis data untuk mengetahui ada atau tidaknya pengaruh variabel bebas terhadap variabel terikat menggunakan metode analisis regresi berganda dengan pengolahan data menggunakan program SPSS. Persamaan sumber dari Soegiyono (2010 : 257 ) sebagai berikut :

Regresi Berganda $\quad: \mathrm{Y}=\mathrm{a}+\beta 1 \mathrm{X} 1+\beta 2 \mathrm{X} 2+\beta 3 \mathrm{X} 3+\mathrm{e}$

Dimana :

Y : Profitabilitas

X1 : Rata-rata Perputaran Kas

X2 : Rata-rata Perputaran Piutang

X3 : Rata-rata Perputaran Persediaan

a : Konstanta

$\beta$ : Koefisien Regresi

e : Variabel residual

Besarnya konstanta tercermin dalam $\alpha$, dan besarnya koefisien dari masingmasing variabel independen ditunjukkan dengan $\beta 1, \beta 2$, dan $\beta 3$, sedangkan variabel dependennya adalah Profitabilitas.

\section{RANCANGAN ANALISIS KOEFISIEN DETERMINASI $\left(\mathbf{R}^{2}\right)$}

Pengujian dengan menggunakan uji koefisien determinasi (R2) yaitu untuk melihat besarnya pengaruh variabel bebas (Situmorang dan Lutfi, 2011:196). R2 
digunakan untuk ketepatan yang paling baik dari analisis regresi berganda. R2 mendekati 1 (satu) maka dapat dikatakan semakin kuat kemampuan variabel bebas dalam model regresi tersebut dalam menerangkan variable terikatnya. Sebaliknya jika R2 mendekati 0 (nol) maka semakin lemah variabel bebas menerangkan variabel terikat. Selain itu perlu juga dicari besarnya koefisien determinasi (R2) parsialnya untuk masing-masing variabel bebas. Menghitung R2 digunakan untuk mengetahui sejauh mana sumbangan dari masing-masing variabel bebas, jika variabel lainnya konstan terhadap variabel terikat. Semakin besar nilai R2 maka semakin besar variasi sumbangannya terhadap variabel terikat.

\section{Uji Hipotesis}

\section{Uji Hipotesis (Uji t)}

Penelitian ini merupakan penelitian yang bertujuan untuk mengetahui pengaruh variabel independen $(\mathrm{X})$ terhadap variabel dependen $(\mathrm{Y})$. Oleh karena itu untuk mengetahui hubungan antara variabel digunakan persamaan regresi sederhana dan berganda. Pengujian terhadap hipotesis yang dilakukan dalam penelitian ini dilakukan dengan cara sebagai berikut :

1. Uji t-statistik pada dasarnya menunjukkan seberapa jauh pengaruh satu variabel bebas secara individual dalam menerangkan variasi variabel independen (Ghozali, 2002 : 44). Sedangkan, menurut Situmorang dan Lutfi (2011:157) menyatakan untuk menguji apakah hipotesis yang diajukan diterima atau ditolak digunakan statistik $\mathrm{t}$ (uji t). apabila thitung > ttabel atau (-thitung) > (-ttabel) pada signifikan $\alpha=5 \%$, dikatakan variabel bebas memiliki pengaruh secara signifikan terhadap variabel terikat sebaliknya thitung $\leq$ ttabel atau (-thitung) $\geq$ (-ttabel) berarti bahwa variabel bebas tidak berpengaruh secara signifikan terhadap variabel terikat secara individual.

2. Uji F-Statistik

Uji F-statistik pada dasarnya menunjukkan apakah semua variabel bebas yang dimasukkan dalam model regresi mempunyai pengaruh secara simultan terhadap variabel terikat (Ghozali, 2002:44). Arti dari simultan adalaah jika salah satu variabel bebas dalam penelitian signifikan terhadap variabel bebas. Tingkat signifikasi yang digunakan dalam penelitian ini $\alpha=5 \%$. Derajat kebebasan (degree of freedom) $\mathrm{df}=(\mathrm{n}-\mathrm{k})$ dimana $\mathrm{n}$ adalah jumlah observasi, $\mathrm{k}$ adalah jumlah variabel bebas. Ftabel akan dicari berdasarkan tingkat signifikasi. Jika Fhitung > Ftabel hal ini berarti variabel bebas mampu menjelaskan variabel terikat secara simultan / bersama. Sebaliknya jika Fhitung < Ftabel, hal ini berarti bahwa variabel bebas secara bersama-sama tidak mampu memnjelaskan variabel terikatnya.

\section{HASIL DAN PEMBAHASAN}

A. Analisis Deskriptif

1) Uji Normalitas

Uji normalitas bertujuan untuk menguji apakah variabel terikat dan variabel bebas dalam model regresi mempunyai distribusi normal atau tidak. Model regresi yang baik adalah yang memiliki distribusi normal atau mendekati normal. Uji normalitas bertujuan untuk menguji apakah variabel terikat dan variabel bebas dalam model regresi mempunyai distribusi normal atau tidak. Model regresi yang baik adalah yang memiliki distribusi normal atau mendekati 
normal. Pada pengujian Normalitas dengan Uji One Sample KolmogorovSmirnov Test tersebut, data terdistribusi secara normal jika nilai Asymp Sig (2tailed) yang dihasilkan lebih besar dari nilai alpha yaitu sebesar 0,05 (5\%). Jika nilai signifikansi $<0,05$ maka distribusi data tidak normal. Pada penelitian ini nilai asymp sebesar 0,009 yang artinya lebih kecil dari nilai alpha sebesar 0,05 (5\%). Maka dengan hal ini berarti H0 ditolak yang berarti data residual terdistribusi tidak normal.

2) Uji Asumsi Klasik

Berdasarkan analisis Asumsi Klasik dapat disimpulkan bahwa analisis regresi sederhana dan berganda dari variabel independen Perputaran Kas (X1), Perputaran Piutang (X2), dan Perputaran Persediaan (X3) terhadap variabel dependen Profitabilitas (Y) memenuhi syarat korelasi, karena :

1. Uji Normalitas Data, titik-titik menyebar data berada di sekitar garis diagonal, dan penyebarannya menjauhi arah garis diagonal. Sehingga, model regresi ini menyalahi asumsi normalitas.

2. Uji Multikolinieritas, model regresi tersebut tidak terdapat problem multikolinieritas baik berdasarkan pada besaran VIF maupun besaran korelasi antar variabel.

3. Uji Autokorelasi, model regresi ini menyimpulkan bahwa tidak terdapat masalah autokorelasi.

4. Uji Heterokedisitas, pada model regresi tersebut tidak terjadi heteroskedisitas, maka model regresi layak digunakan untuk prediksi regresi.

\section{B. Pengujian Hipotesis}

\section{a. Pengujian Pengaruh Parsial (Uji t-statistik)}

1. Pengujian secara parsial Variabel Perputaran Kas pada tabel 4.10 memiliki nilai t hitung sebesar 0.293 , dan nilai profitabilitas signifikansi 0,770. Nilai signifikasi ini lebih besar dari pada 0,05. Dengan demikian dapat disimpulkan bahwa Perputaran Kas berpengaruh Positif dan tidak Signifikasi terhadap Profitabilitas. Sehingga hipotesis 1 yang menyatakan bahwa terdapat pengaruh parsial perputaran kas terhadap profitabilitas diterima.

2. Pengujian secara parsial Variabel perputaran Piutang pada tabel 4.10 memiliki nilai t hitung sebesar 0.159 dan nilai signifikasi 0,874 . Nilai signifikasi ini lebih besar dari pada 0,05. Dengan demikian dapat disimpulkan bahwa Perputaran Piutang berpengaruh positif dan tidak signifikan terhadap Profitabilitas. Sehingga hipotesis 2 yang menyatakan bahwa terdapat pengaruh parsial perputaran piutang terhadap profitabilitas diterima.

3. Pengujian secara parsial Variabel Perputaran Persediaan memiliki nilai $t$ hitung sebesar 4.122 dan nilai signifikasi 0,000. Nilai signifikasi 0,000 lebih kecil dari 0,05. Dengan demikian dapat disimpulkan bahwa Perputaran Persediaan berpengaruh Positif dan Signifikan terhadap Profitabilitas. Sehingga, hipotesis 3 yang menyatakan bahwa terdapat pengaruh parsial terhadap profitabilitas diterima.

\section{b. Pengujian Pengaruh Simultan atau bersama-sama (Uji F)}

Berdasarkan hasil uji $\mathrm{F}$ menunjukkan bahwa nilai Fhitung sebesar 6,456 dan nilai signifikasi 0,000 . Dimana nilai signifikasi ini signifikan terhadap tingkat signifikasi 0,05 karena lebih kecil dari 0,05 maka model regresi dapat digunakan untuk memprediksi Profitbilitas atau dapat dikatakan variabel Perputaran Kas, 
Perputaran Piutang dan Perputaran Persediaan secara bersama-sama berpengaruh terhadap Profitabilitas. Dengan demikian hipotesis 4 yang menyatakan terdapat pengaruh secara simultan antara variabel perputaran kas, perputaran piutang dan perputaran persediaan terhadap profitabilitas diterima.

\section{Pembahasan Deskriptif}

Adapun pembahasan dari metode deskriptif mengenai masing-masing variabel dalam penelitian ini dapat diuraikan sebagai berikut.

1. Perputaran Kas

Rata-rata Perputaran Kas dari tahun 2010 sampai dengan tahun 2014 adalah 20, $61 \mathrm{x}$, sedangkan nilai maksimum untuk variabel Perputaran Kas adalah sebesar 172.96 x yang terjadi pada triwulan ketiga tahun 2014 pada PT. Nipres, Tbk. Standar deviasi adalah 28, 25 persen lebih tinggi dari rata-rata perputaran kas periode 2010-2014, ini menunjukkan tidak stabilnya perputaran kas perusahaan sektor otomotif dan komponen yang terdaftar di Bursa Efek Indonesia pada tahun 2010-2014. Secara teori semakin tinggi perputaran kas berarti makin cepat kembalinya uang melalui penjualan. Sebaliknya, apabila perputaran kas rendah maka perputaran kas lebih lama kembalinya uang melalui penjualan. Dalam penelitian ini menunjukkan bahwa perusahaan sektor otomotif dan komponen di BEI rata-rata memiliki perputaran kas yang rendah karena rata-rata perputaran kas lebih rendah dari standar deviasi. Rendahnya tingkat perputaran kas ini menunjukkan bahwa perusahaan dalam sektor otomotif dan komponen belum efisien dalam penggunaan kas.

2. Perputaran Piutang

Rata-rata Perputaran Piutang dari tahun 2010-2014 adalah 3, 47 x, sedangkan nilai maksimum untuk varibel Perputaran Piutang adalah sebesar 15, 20 x yang terjadi pada triwulan 4 tahun 2010 pada PT. Multistrada Arah Sarana, Tbk. Standar deviasi adalah 2, 48 persen rendah dari rata-rata Perputaran Piutang periode 20110-2014, hal ini menunjukkan stabilnya perputaran piutang perusahaan sektor otomotif dan komponen yang terdata di bursa efek Indonesia pada tahun 2010-2014. Secara teori semakin tinggi perputaran piutang maka semakin cepat dana yang di investasikan pada piutang dagang dapat ditagih menjadi uang tunai atau menujukkan modal kerja yang tertanam rendah. Dalam penelitian ini menunjukkan bahwa perusahaan sektor otomotif dan komponen rata-rata memiliki kemampuan perputaran piutang yang tinggi.

3. Perputaran Persediaan

Rata-rata perputaran persediaaan dari tahun 2010-2014 adalah 3,86 x, sedangkan nilai maksimum 20,17 x yang terjadi pada triwulan empat tahun 2013 pada PT Astra International Tbk. Standar deviasi adalah 3,36 persen lebih rendah dari rata-rata perputaran persediaan periode 2010-2014. Secara teori semakin tinggi perputaran persediaan maka semakin cepat perputaran persediaan yang berarti akan semakin efisien penggunaan persediaan dalam satu perusahaan. Dalam penelitian ini menunjukkan bahwa perusahaan sektor otomotif dan komponen memiliki kemampuan penggunaan perputaran persediaan yang efisien. 
4. Profitabilitas pada perusahaan otomotif dan komponen yang tergabung di BEI tahun 2010-2014. Rata-rata Profitabilitas dari tahun 2010-2014 adalah 99 persen, sedangkan nilai maksimum untuk varibel Profitabilitas adalah sebesar 75 persen yang terjadi pada triwulan 3 tahun 2014 pada PT. Astra International Tbk. Standar deviasi adalah 0,13 persen rendah dari rata-rata Profitabilitas periode 20110-2014, hal ini menunjukkan stabilnya profitabilitas perusahaan sektor otomotif dan komponen yang terdata di bursa efek Indonesia pada tahun 2010-2014. Secara teori semakin tinggi perputaran piutang maka semakin baik operasi Perusahaan. Dalam penelitian ini menunjukkan bahwa perusahaan sektor otomotif dan komponen rata-rata memiliki kemampuan profitabilitas yang tinggi.

\section{Pembahasan Verifikatif}

1. Pengaruh Perputaran Kas, Perputaran Piutang, Perputaran Persediaan secara simultan terhadap Profitabilitas pada perusahaan otomotif dan komponen yang tergabung di BEI tahun 2010-2014. Berdasarkan hasil uji F di atas menunjukkan bahwa nilai Fhitung sebesar 6,456 dan Ftabel sebesar 2.67 (didapat dari N = 140; df $1=4-1=3$ dan df2 = 140-4 = 136, maka NIlai F Tabel adalah 2.67). Karena Fhitung lebih besar daripada Ftabel, dan nilai p-value adalah 0.00 (sig) lebih kecil dari alpha 0.05 (confidence interval), maka dapat disimpulkan bahwa koefisien regresi secara keseluruhan adalah signifikan pada tingkat 5\%, Dimana Ho ditolak dan H1 diterima. Dengan demikian hal ini menunjukkan bahwa terdapat pengaruh yang signifikan secara bersama-sama antara Perputaran Kas, Perputaran Piutang dan Perputaran Persediaan terhadap Profitabilitas.

2. Berdasarkan Uji Koefisien korelasi (R) sebesar 0,353 menunjukkan hubungan antara variabel Perputaran Kas, Perputaran Piutang, Perputaran Persediaan Terhadap Profitabilitas adalah positif 0,353. Hubungan sebesar 0,353 membuktikan bahwa hubungan antara variabel Perputaran Kas, Perputaran Piutang, Perputaran Persediaan dengan Profitabilitas adalah cukup.

3. Koefisien determinasi (R2) menggunakan adjusted R square sebesar 0,105, hasil tersebut menunjukkan bahwa besarnya Profitabilitas yang dapat dijelaskan oleh variabel Perputaran Kas, perputaran piutang dan Perputaran Persediaan adalah sebesar $10,5 \%$ dan yang dijelaskan oleh variabel lain di luar model sebesar 89,5\% (100\%-10,5\%). Dengan demikian Perputaran kas, perputaran piutang dan perputaran persediaan apabila dilakukan secara bersama-sama, maka akan meningkatkan Profitabilitas sebesar 10,5\%.

4. Pengaruh Perputaran Kas, Perputaran Piutang, Perputaran Persediaan secara parsial terhadap Profitabilitas pada perusahaan otomotif dan komponen yang tergabung di BEI tahun 2010-2014.

a. Perputaran Kas

Berdasarkan hasil penelitian secara parsial diperoleh bahwa Perputaran Kas berpengaruh positif tidak signifikan terhadap Profitabilitas. Secara teori Perputaran Kas merupakan perbandingan hasil pendapatan atau penjualan dengan rata-rata kas pada periode tertentu, perputaran kas yang tinggi semakin baik, karena semakin tinggi perputaran kas maka semakin cepat pula kembalinya uang melalui penjualan. Perputaran kas berfungsi untuk mengukur tingkat kecukupan modal kerja perusahaan yang dibutuhkan untuk membayar tagihan dan membiayai penjualan. Hasil penelitian ini membantahkan penelitian yang 
dilakukan oleh Mohammad Tejo Suminar (2014) yang diperoleh bahwa Perputaran Kas berpengaruh negatif dan signifikan terhadap Profitabilitas, sedangkan Perputaran Piutang dan Perputaran Persediaan memiliki pengaruh Positif terhadap Profitabilitas.

b. Perputaran Piutang

Berdasarkan hasil penelitian secara parsial diperoleh bahwa Perputaran Piutang memiliki pengaruh positif tidak signifikan. Secara teori perputaran piutang merupakan perbandingan hasil pendapatan atau penjualan dengan rata-rata piutang pada periode tertentu. Semakin tinggi tingkat perputaran piutang menunjukkan modal kerja yang ditanamkan dalam piutang rendah. Dengan semakin tingginya perputaran piutang maka laba yang dihasilkan perusahaan semakin baik. Hasil penelitian ini mendukung penelitian yang dilakukan oleh Nina Sufiana dan Ni Ketut Purnawati (2013) yang diperoleh bahwa Perputaran kas tidak berpengaruh signifikan dan memiliki arah yang negative secara parsial terhadap profitabilitas, sedangkan perputaran piutang dan perputaran persediaan berpengaruh positif terhadap Profitabilitas.

c. Perputaran Persediaan

Berdasarkan hasil penelitian secara parsial Variabel Perputaran Persediaan memiliki nilai t hitung sebesar 4.122 dan nilai signifikasi 0,000. Nilai signifikasi 0,000 lebih kecil dari 0,05. Dengan demikian dapat disimpulkan bahwa Perputaran Persediaan berpengaruh Positif dan Signifikan terhadap Profitabilitas. Hasil penelitian ini mendukung penelitian yang dilakukan oleh Mohamad Tejo Suminar yang diperoleh bahwa Perputaran Persedian dan Perputaran Piutang berpengaruh Positif terhadap Profitabilitas ROA dan ROE.

\section{SIMPULAN DAN SARAN}

\section{a. Simpulan}

Berdasarkan hasil penelitian dan pembahasan pada bab-bab sebelumnya dapat dikemukakan beberapa kesimpulan sebagai berikut : Perputaran Kas, Perputaran Piutang, dan Perputaran Persediaan pada perusahaan otomotif dan komponen yang terdapat di BEI tahun 2010-2014 antara lain: Perputaran Kas memiliki ratarata paling tinggi sebesar 58,95 sedangkan paling rendah sebesar 7,34. PT. Nipres Tbk (NIPS) memiliki rata-rata paling tinggi, sedangkan PT. Astra Otoparts (AUTO) memiliki rata-rata paling rendah. Perputaran Piutang memiliki rata-rata paling tinggi sebesar 6,17, sedangkan paling rendah sebesar 2,29. PT. Multistrada Arah Sarana, Tbk memiliki rata-rata paling tinggi, sedangkan PT. Nipres Tbk memiliki rata-rata terendah. Perputaran Persediaan memiliki ratarata paling tinggi sebesar 9,33, sedangkan paling rendah 1,74. PT. Astra Internasional Tbk memiliki rata-rata paling tinggi, sedangkan PT. Prima Alloy Steel Universal Tbk memilliki rata-rata terendah. Profitabilitas pada perusahaan otomotif dan komponen yang terdapat di BEI tahun 2010-2014 mengalami perkembangan yang fluktuatif dimana Profitabilitas memiliki rata-rata paling tinggi sebesar 0,18 sedangkan paling rendah sebesar 0,04. PT. Astra Internasional Tbk memiliki rata-rata paling tinggi, sedangkan PT. Nipres Tbk memiliki rata-rata paling rendah. Pengaruh Perputaran Kas, Perputaran Piutang, Perputaran Persediaan secara simultan terhadap Profitabilitas pada perusahaan otomotif dan komponen yang terdapat di BEI tahun 2010-2014 antara lain : 
Berdasarkan hasil penelitian secara simultan Perputaran Kas, Perputaran Piutang dan Perputaran Persediaan terdapat pengaruh terhadap Profitabilitas.

Koefisien Determinasi (Adjusted R2) menunjukkan bahwa Perputaran Kas, Perputaran Piutang dan Perputaran Persediaan memberikan kontribusi terhadap variabel Profitabilitas sebesar 10,,5 \%, sedangkan sisanya dipengaruhi oleh faktor-faktor lain yang tidak diteliti.

Berdasarkan Hasil Uji F bahwa Fhitung=6,456 dan Ftabel=2,67, berarti Fhitung lebih besar dari Ftabel dan nilai sig $=0.00$ lebih kecil dari alpha 0,05. Sehingga, dapat disimpulkan bahwa H0 ditolak dan H1 diterima. Dengan demikian hal ini menunjukkan bahwa terdapat pengaruh yang signifikan secara bersama-sama antara Perputaran Kas, Perputaran Piutang dan Perputaran Persediaan terhadap Profitabilitas. Pengaruh Perputaran Kas, Perputaran Piutang, Perputaran Persediaan secara parsial terhadap Rasio Profitabilitas pada perusahaan otomotif dan komponen yang terdapat di BEI tahun 2010-2014 antara lain : Pengaruh Perputaran Kas terhadap Profitabilitas. Berdasarkan hasil penelitian secara parsial Perputaran Kas memiliki pengaruh positif yang tidak disgnifikan terhadap Profitabilitas. Secara Teori Perputaran Kas merupakan perbandingan hasil pendapatan atau penjualan dengan selisih kas pada periode tertentu, perputaran kas yang tinggi semakin baik, karena semakin tinggi perputaran kas maka semakin cepat pula kembalinya uang melalui penjualan. perputaran kas berfungsi untuk mengukur tingkat kecukupan modal kerja perusahaan yang dibutuhkan untuk membayar tagihan dan membiayai penjualan. Dalam penelitian ini menunjukkan bahwa perusahaan sektor otomotif dan komponen di BEI rata-rata memiliki perputaran kas yang rendah karena rata-rata perputaran kas lebih rendah dari standar deviasi. Rendahnya tingkat perputaran kas ini menunjukkan bahwa perusahaan dalam sektor otomotif dan komponen belum efisien dalam penggunaan kas. Hasil penelitian ini tidak mendukung penelitian yang dilakukan oleh Mohammad Tejo Suminar (2014) yang diperoleh bahwa Perputaran Kas berpengaruh negatif dan signifikan terhadap Profitabilitas, sedangkan Perputaran Piutang dan Perputaran Persediaan memiliki pengaruh Positif terhadap Profitabilitas. Pengaruh Perputaran Piutang terhadap Profitabilitas. Berdasarkan hasil penelitian secara parsial diperoleh bahwa Perputaran Piutang memiliki pengaruh positif tidak signifikan. Secara teori perputaran piutang merupakan perbandingan hasil pendapatan atau penjualan dengan rata-rata piutang pada periode tertentu. Semakin tinggi tingkat perputaran piutang menunjukkan modal kerja yang ditanamkan dalam piutang rendah. Dengan semakin tingginya perputaran piutang maka laba yang dihasilkan perusahaan semakin baik. Hasil penelitian ini mendukung penelitian yang dilakukan oleh Nina Sufiana dan Ni Ketut Purnawati (2013) yang diperoleh bahwa Perputaran kas tidak berpengaruh signifikan dan memiliki arah yang negative secara parsial terhadap profitabilitas, sedangkan perputaran piutang dan perputaran persediaan berpengaruh positif terhadap Profitabilitas. Pengaruh Perputaran Persediaan terhadap Profitabilitas. Berdasarkan hasil penelitian secara parsial Perputaran Persediaan memiliki pengaruh positif signifikan terhadap Profitabilitas. Secara teori semakin tinggi perputaran persediaan maka semakin cepat perputaran persediaan yang berarti akan semakin efisien penggunaan persediaan dalam satu perusahaan. Dalam penelitian ini menunjukkan bahwa perusahaan sektor otomotif dan komponen memiliki 
kemampuan penggunaan perputaran persediaan yang efisien. Hasil penelitian ini mendukung penelitian yang dilakukan oleh Mohammad Tejo Suminar (2014) yang diperoleh bahwa Perputaran Kas berpengaruh negatif dan signifikan terhadap Profitabilitas, sedangkan Perputaran Piutang dan Perputaran Persediaan memiliki pengaruh Positif terhadap Profitabilitas.

\section{b. Saran}

Berdasarkan hasil Pembahasan dan kesimpulan pada bab-bab sebelumnya dapat dikemukakan beberapa saran yang diharapkan dapat berguna bagi pihak terkait sebagai berikut :

1. Perputaran Kas memiliki pengaruh positif tidak signifikan terhadap Profitabilitas, dalam hal ini sebaiknya perusahaan tetap memperhatikan perputaran kas dan meningkatkannya karena apabila perputaran kas ditingkatkan maka perusahaan akan lebih stabil melakukan penjualannya. Sehingga profitabilitas yang dimiliki perusahaan akan semakin tinggi.

2. Perputaran Piutang memiliki pengaruh positif tidak signifikan terhadap Profitabilitas, perusahaan harus tetap meningkatkan perputaran piutang karena semakin cepat dana yang di investasikan pada piutang dagang dapat ditagih menjadi uang tunai atau menujukkan modal kerja yang tertanam rendah. Dengan demikian, profitabilitas yang dimiliki perusahaan semakin tinggi.

3. Perputaran Persediaan memiliki pengaruh positif signifikan terhadap Profitabilitas, maka sebaiknya perusahaan tetap mengontrol perputaran persediaan agar tetap stabil dan meningkat akan lebih baik, karena apabila perputaran persediaan menurun maka tingkat Profitabilitas perusahaan pun akan menurun.

\section{DAFTAR PUSTAKA}

Ghazali, Imam.2006.Aplikasi Analisis Multivariate Cetakan IV. Semarang:Badan Penerbit Universitas Dipenogoro.

Harjito, Agus. 2010. Manajemen Keuangan, Edisi ketiga.Yogyakarta : Ekonisia.

Ikatan Akuntansi Indonesia.2007.Standar Akuntansi Keuangan.Jakarta: Salemba Empat.

James C. Van Horne dan John M. Wachowichz.2005. Prinsip-prinsip Manajemen Keuangan. Edisi kedua belas. Jakarta : Salemba Empat.

Kasmir.2014.Analisa Laporan Keuangan.Jakarta: Raja Grafindo Persada.

Ksenija Dencic-Mihaljov. 2015.Impact of Account Receivable Management On The Profitability During The Financial Crisis. Eropa: University of Nis

Mamduh M. Hanafi dan Abdul Halim. 2002. Analisa laporan Keuangan. Yogyakarta: UPP AMP YKPN.

Munawir S.2007. Analisa Laporan Keuangan.Yogyakarta: UPP-AMP YKPN.

Riyanto, Bambang, 2011.Dasar-dasar Pembelanjaan Perusahaan, Edisi Keempat. Yogyakarta: BPFE.

Sartono, Agus. 2009. Manajemen Keuangan : Teori \& Aplikasi, Cetakan Pertama, Edisi Keempat. Yogyakarta : BPFE.

Sawir, Agnes, 2009. Analisa Kinerja Keuangan dan Perencanaan keuangan Perusahaan. Jakarta: PT. Gramedia Pustaka Utama,.

Sirait, Alfonsus.2013. Manajemen Keuangan.Jakarta: Erlangga. 
Sufiana, Nina dan Ni Ketut Purnawati.2013.Pengaruh Perputaran Kas, Perputaran Piutang Dan Perputaran Persediaan Terhadap Profitabilitas.Bali: Universitas Udayana.

Sugiyono.2010.Metode Penelitian Kuantitatif Kualitatif dan R\&D.Bandung: Alfabeta.

Suminar, Mohamad Tejo.2015.Pengaruh perputaran persediaan, perputaran piutang dan perputaran kas terhadap profitabilitas pada perusahaan sektor industri barang konsumsi yang terdaftar di BEI periode 2008-2013.Semarang: Universitas Pandaran.

Sutarti dan Adi Sulaeman.2011. Pengaruh arus kas operasi terhadap pertumbuhan laba perusahaan Studi Kasus pada PT Multi Manunggal.Bogor: STIE Kesatuan.

Sutrisno, 2009. Manajemen Keuangan Teori, Konsep dan Aplikasi. Yogyakarta: Ekonisia.

Syafri Harahap, Sofyan, 2008. Analisa Kritis atas Laporan Keuangan. Jakarta: PT. Raja Grafindo Persada.

Syamsuddin, Lukman, 2001. Manajemen Keuangan Perusahaan, Jakarta: PT. Raja Grafindo Persada.

Umar, Husein.2009.Metode Penelitian Untuk Skripsi dan Tesis. Jakarta: PT. Raja Grafindo Persada.

Wild, John, K.R. Subramanyam, dan Robert F. Halsey.2005.Analisa Laporan Keuangan.Jakarta: Salemba Empat. 
